Check for updates

Cite this: React. Chem. Eng., 2019, 4, 2129

Received 2nd September 2019, Accepted 18th October 2019

DOI: 10.1039/c9re00361d

rsc.li/reaction-engineering

\title{
Calcination kinetics of cement raw meals under various $\mathrm{CO}_{2}$ concentrations
}

\author{
Jose Ramon Fernandez, (D)* Sandra Turrado and Juan Carlos Abanades
}

\begin{abstract}
The calcium looping $\mathrm{CO}_{2}$ capture process, $\mathrm{CaL}$, represents a promising option for the decarbonisation of cement plants, due to the intrinsic benefit of using the spent $\mathrm{CO}_{2}$ sorbent as a feedstock for the plant. The generation of sufficiently active $\mathrm{CaO}$ from the raw meals entering the cement plant for the $\mathrm{CO}_{2}$ capture requires calcination of these materials at around $900{ }^{\circ} \mathrm{C}$ in various atmospheres of $\mathrm{CO}_{2}$. This work investigates the calcination kinetics of fine particles $(<50 \mu \mathrm{m})$ of limestone, natural marls and raw meals in a drop tube reactor, under conditions very similar to those expected in suspension calciners of CaL systems. Experiments have been carried out with very short gas-solid contact times $(t<2 \mathrm{~s})$ and various concentrations of $\mathrm{CO}_{2}$ (up to $85 \mathrm{vol} \%$ ). High calcination conversions have been measured under these conditions with all the materials tested regardless of their origin and composition. The kinetic rates of $\mathrm{CaCO}_{3}$ decomposition depend on the BET surface area of the solid, which is consistent with the model reported by Borgwardt, AlChE J., 1985, 31, 103-111, and yield consistent activation energy (i.e. 195 kJ $\mathrm{mol}^{-1}$ ) and pre-exponential factors when using a dependency on $\mathrm{CO}_{2}$, as proposed by J. M. Valverde, P. E. Sanchez-Jimenez and L. A. Perez-Maqueda, J. Phys. Chem. C, 2015, 119, 1623-1641.
\end{abstract}

\section{Introduction}

Calcium looping $(\mathrm{CaL})$ is an emerging $\mathrm{CO}_{2}$ capture process that has experienced a great development in terms of technology readiness level over the last decade, principally in post-combustion applications, ${ }^{3-5}$ after testing in several pilot plants on a scale of up to $2 \mathrm{MW} \cdot{ }^{6-8} \mathrm{CO}_{2}$ reacts with calcium oxide to form calcium carbonate in the carbonator at temperatures around $650{ }^{\circ} \mathrm{C}$, and the carbonated solids circulate to the calciner, where they are regenerated to produce a rich stream of $\mathrm{CO}_{2}$. The decomposition of $\mathrm{CaCO}_{3}$ to $\mathrm{CaO}$ with a high concentration of $\mathrm{CO}_{2}$ in the gaseous phase requires temperatures close to $900{ }^{\circ} \mathrm{C}$ according to equilibrium. Although a wide variety of procedures are reported in the literature to accomplish this highly energydemanding calcination operation (e.g. indirect heating through high-temperature walls, ${ }^{9-12}$ heat transfer using solids at high temperature ${ }^{13-15}$ or direct heating via chemical looping reactions ${ }^{16,17}$ ), the oxy-fuel calcination is still the most investigated at a large pilot-plant scale. ${ }^{18}$

Calcium looping seems particularly suitable for the $\mathrm{CO}_{2}$ capture in cement plants ${ }^{19,20}$ mainly because the same calcium-based raw meal, once it has been calcined, can be used both as a $\mathrm{CO}_{2}$ sorbent and as a feedstock for the production of clinker. ${ }^{21-23}$ Moreover, the integration of

Spanish Research Council, INCAR-CSIC, Francisco Pintado Fe, n. 26, 33011 Oviedo, Spain.E-mail: jramon@incar.csic.es calcium looping in existing cement plants is simpler than other promising alternatives, such as the oxy-fuel combustion in the kiln, ${ }^{24-26}$ since the operation of the kiln and the clinker cooler is analogous to those in conventional cement plants without $\mathrm{CO}_{2}$ capture. ${ }^{27-30}$ Finally, the excess heat in the CaL process can be efficiently recovered in a steam cycle thanks to the high operating temperatures in the carbonator and the calciner. The power generated can then partially compensate for the energy required for the air separation unit and for the $\mathrm{CO}_{2}$ compressor, thereby reducing the energy penalty of the $\mathrm{CO}_{2}$ capture operation. ${ }^{31-33}$

Different configurations have been proposed for the integration of calcium looping processes into cement plants. One alternative is the tail-end arrangement, where both carbonator and calciner reactors are independent units and the integration with the cement plant is carried out through introduction of the feed into the carbonator of the flue gas exiting the kiln and through purging $\mathrm{CaO}$ from the calciner, which replaces some of the calcium oxide required for the clinker production. This configuration allows the operation in fluidized-bed reactors in a similar way to post-combustion CaL systems envisaged for the $\mathrm{CO}_{2}$ capture in power plants, which reduces the uncertainties of this technology and facilitates its scaling-up. ${ }^{27,28,31}$ In recent studies, the feasibility of this arrangement has been experimentally demonstrated in pilot plants of $30 \mathrm{~kW}_{\text {th }}$ (ref. 34) and 200 $\mathrm{kW}_{\mathrm{th}} \cdot{ }^{35}$ However, the operation of interconnected fluidized beds requires relatively large particles (i.e. between 100 and 
$200 \mu \mathrm{m}$ ), which imposes a subsequent milling stage to obtain the typical particle size used in cement plants (i.e. below 30 $\mu \mathrm{m})$ and ensure the quality of the clinker.

In a highly integrated $\mathrm{CaL}$ arrangement, the pre-calciner of the cement plant is replaced by an oxy-fired calciner. ${ }^{21,29,32}$ A large fraction of the calcined solids is sent to the kiln and the remaining solids circulate to the carbonator to react with the $\mathrm{CO}_{2}$ of the flue gas exiting the kiln ${ }^{30}$ (see Fig. 1). In this configuration, the energy demand is reduced leading to a higher energy efficiency of the $\mathrm{CO}_{2}$ capture process. ${ }^{32}$ The $\mathrm{CO}_{2}$ sorbent is preferably calcined raw meal ${ }^{29,30}$ (instead of $\mathrm{CaO}$ from limestone ${ }^{21}$ ), which also contains $\mathrm{SiO}_{2}$ among other compounds required for clinker production. During calcination, calcium silicates can then be formed resulting in a decrease in the $\mathrm{CO}_{2}$ carrying capacity of the calcium-based sorbent. ${ }^{36,37}$ Very fine solids are preferred in this integrated configuration to avoid any alteration in the operation of the kiln, so that entrained flow reactors are the preferable option. ${ }^{29,32}$ Although the performance of this type of reactor is well-known in the cement sector (the pre-calciners and raw meal pre-heaters are typically entrained flow beds), there are still multiple uncertainties for their application in CaL systems. In particular, only limited information has been reported so far about the calcination and carbonation of very fine particles of cement raw meal under the typical operating conditions of entrained bed reactors. ${ }^{38}$ The carbonation kinetics of several CaO-based materials with a particle size of about $50 \mu \mathrm{m}$ on the scale of 1-5 seconds has been determined in a recent study. ${ }^{39}$ Analogous experimental and modelling work for the calcination reaction is of high interest for the future scaling-up of the entrained-bed calcium looping technology, and this is the main objective of the present work.

For the conditions of interest in this work, the existing knowledge on the thermal decomposition of $\mathrm{CaCO}_{3}$ suggests that this can be limited by three controlling stages: heat transfer from the gas phase to the reaction surface, the intrinsic chemical reaction and the mass transfer of $\mathrm{CO}_{2}$ resulting from the calcination reaction to the gas phase. ${ }^{1,40}$

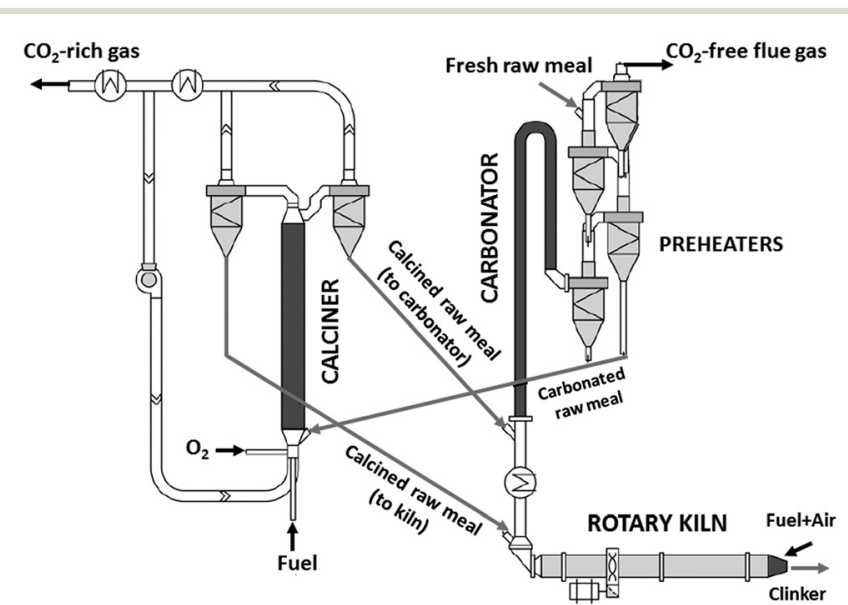

Fig. 1 Scheme of a calcium looping arrangement highly integrated in a cement plant.
The contribution of every resistance to the overall reaction is greatly influenced by the operating conditions, the experimental device and the particle size. ${ }^{40}$ It is generally accepted that the contribution of heat transfer to the calcination kinetics becomes less important as the particle size decreases, ${ }^{1,40-49}$ which makes both the chemical reaction and $\mathrm{CO}_{2}$ mass transfer from the solid surface to the bulk gas the most important controlling stages for the calcination of cement raw meals. Borgwardt ${ }^{1}$ observed that the chemical reaction is the controlling step for solids with particle sizes below $90 \mu \mathrm{m}$, with the calcination rate being directly related to the surface area of the solid. $\mathrm{Hu}$ and Scaroni ${ }^{47}$ used the equation proposed by Borgwardt ${ }^{1}$ while also considering resistances to heat and $\mathrm{CO}_{2}$ mass transfer, which become more relevant for larger particles and calcination temperatures higher than $1000{ }^{\circ} \mathrm{C}$. The calcination of $\mathrm{CaCO}_{3}$ particles with initially low porosity has been typically described using a shrinking core model (SCM), in which the reaction rate is proportional to the difference between the equilibrium partial pressure and the $\mathrm{CO}_{2}$ partial pressure. ${ }^{41-44,46,48,50-52}$ When the calcination is carried out under $\mathrm{CO}_{2}$-rich atmospheres, an induction period is usually observed at low solid conversions, which may be caused by pore enlargement as $\mathrm{CaO}$ is formed. Khinast et al. ${ }^{40}$ proposed a random pore model (RPM) to represent the calcination kinetics under these conditions. The grain model developed by Szekely and Evans ${ }^{53}$ has also been used to describe the calcination of $\mathrm{CaCO}_{3}$ assuming that the solids are composed of spherical grains of uniform size and each one is calcined following a SCM pattern. ${ }^{49,54-56}$ García-Labiano et al. ${ }^{48}$ considered that a porous structure is formed during calcination due to the lower molar volume of calcium oxide. The reaction can then be modelled by a changing grain size pattern. Okunev et al. ${ }^{57}$ also assumed the shrinkage of the calcined grains and the formation of $\mathrm{CaO}$ nuclei is the limiting factor for the overall reaction. Valverde et $a .^{2}$ studied specifically the calcination rate of fine particles of limestone (about $10 \mu \mathrm{m}$ ) operating with partial pressures of $\mathrm{CO}_{2}$ and temperatures near equilibrium. They observed that the $\mathrm{CaCO}_{3}$ decomposition rate becomes lower as the calcination temperature increases, whenever the $P_{\mathrm{CO}_{2}} / P_{\text {eq }}$ ratio remains constant. They explained this phenomenon with a two-stage reaction mechanism, in which $\mathrm{CaCO}_{3}$ first decomposes into an intermediate structure with active sites for $\mathrm{CO}_{2}$, and then $\mathrm{CO}_{2}$ is desorbed giving rise to the (exothermic) formation of stable $\mathrm{CaO}$. Recent studies have evaluated the effect of $\mathrm{SO}_{2}$ and steam (both naturally present in the calciner of a CaL system when coal is used as fuel) on the $\mathrm{CaCO}_{3}$ calcination rate. Qin et al. ${ }^{58}$ found that a sulfation reaction can slightly inhibit $\mathrm{CaCO}_{3}$ decomposition but only when there is a great proportion of $\mathrm{CaSO}_{4}$ causing porous blockage, which hinders the diffusion of $\mathrm{CO}_{2}$ from the calcination zone towards the external surface of the particles. He et $a l .{ }^{59}$ studied the catalytic effect of steam on $\mathrm{CaCO}_{3}$ calcination and proposed a reaction mechanism at the atomic level, in which $\mathrm{H}_{2} \mathrm{O}$ is first adsorbed on the $\mathrm{CaCO}_{3}$ 
surface and subsequently forms intermediate compounds $\left(\mathrm{OH}^{*}, \mathrm{H}^{*}, \mathrm{CO}_{3}^{*}\right.$, and $\left.\mathrm{HCO}_{3}^{*}\right)$ that significantly reduce the activation energy of the overall calcination reaction.

In this work, we use the previous background to investigate the calcination of different $\mathrm{CaCO}_{3}$-containing materials under the typical conditions of CaL systems highlyintegrated in cement plants (i.e. mean particle sizes below 50 $\mu \mathrm{m}$, solid/gas contact times of a few seconds, temperatures up to $1000{ }^{\circ} \mathrm{C}$ and reaction atmospheres from air to gases containing up to $85 \mathrm{vol} \% \mathrm{CO}_{2}$ ). Kinetic parameters have been obtained under quasi-differential conditions in an electrically heated drop tube reactor. Both the experimental results and the kinetic model fitting the observations could contribute to the development of the CaL technology for the decarbonisation of cement plants.

\section{Experimental section and material characterization}

A $6.5 \mathrm{~m}$ long and $80 \mathrm{~mm}$ internal diameter drop tube reactor was designed and built at INCAR-CSIC (see Fig. 2) to carry out the calcination tests. Three heating elements connected to independent controllers with a capacity of $3 \times 3.5 \mathrm{~kW}_{\mathrm{e}}$ are installed along the reactor in order to counteract heat losses and maintain a uniform axial temperature profile. The tube is surrounded by a $0.2 \mathrm{~m}$ width layer of glass wool. There are 12 measurement points distributed uniformly along the drop

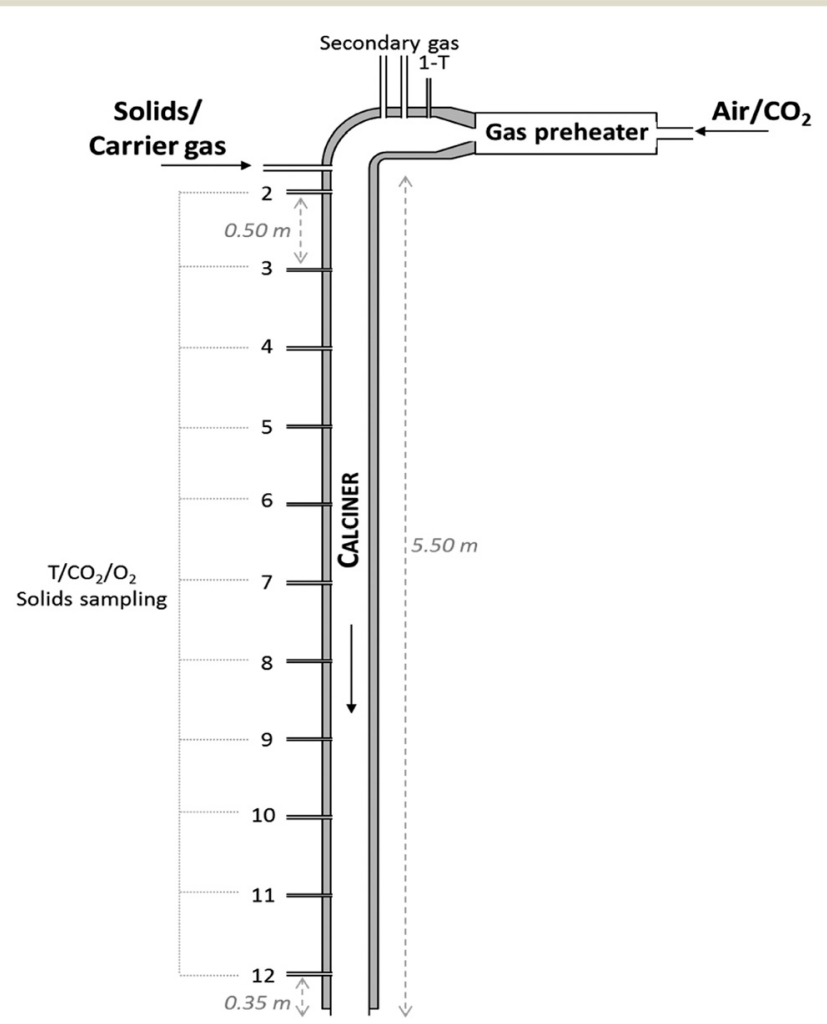

Fig. 2 Scheme of the drop tube reactor used in this work for the determination of calcination kinetics of cement raw meals. tube, which make it possible to evaluate the temperature (by means of K-type thermocouples) and solid/gas compositions at different reaction lengths. Each gas sampling line is equipped with a particulate filter to protect the analysers from the solids. Two analysers (ABB EL3020 and ABB AO2000) equipped with IR (URAS26) and $\mathrm{O}_{2}$ analyser (MAGNOS206) modules and two $\mathrm{CO}_{2}$ Meter ${ }^{\circledR}$ sensors (GC0016 COZIR) have been used to measure online the composition of the gas. The measuring ranges of these analysers are 0-35 vol\% $\quad \mathrm{CO}_{2}$ and $0-100 \quad$ vol\% $\quad \mathrm{CO}_{2}$, respectively. The content of calcium carbonate in the solid samples captured by isokinetic probes has been measured offline with a LECO® ${ }^{\circledR}$ CS230 apparatus, which determines the carbon content by IR analysis. The particles of the raw meals are injected at the top of the drop tube (i.e. at $5.5 \mathrm{~m} \mathrm{high}$ ) together with a carrier gas (air) and move down mixed with the main gas stream composed of air and $\mathrm{CO}_{2}$. An in-house design solids feeding apparatus described in a previous study ${ }^{39}$ has been used for these tests.

A batch of around $150 \mathrm{~g}$ of raw meals has been fed into the reactor during each calcination experiment. Flows of about $0.35 \mathrm{Nm}^{3} \mathrm{~h}^{-1}$ of carrier gas (coming from a compressor at 5 bar) and between 0.2 and $1 \mathrm{~kg} \mathrm{~h}^{-1}$ of solids have been injected during the calcination tests. Both solids and carrier gas have been preheated up to $500{ }^{\circ} \mathrm{C}$ before they entered the reactor. Different air/ $\mathrm{CO}_{2}$ mixtures have been tested (up to 85 vol\% $\mathrm{CO}_{2}$ in air), which have been pre-heated up to $1100{ }^{\circ} \mathrm{C}$ using a Kanthal ${ }^{\circledR}$ electric gas preheater with a capacity of 3.5 $\mathrm{kW}_{\mathrm{e}}$. Air flow rates ranging from 0.5 to $8.3 \mathrm{Nm}^{3} \mathrm{~h}^{-1}$ have been supplied using a blower, while $\mathrm{CO}_{2}$ has come from commercial flasks. Air and $\mathrm{CO}_{2}$ flow rates have been regulated using Bronkhorst mass flow controllers. All the electric signals from the thermocouples, gas analysers and mass flow controllers have been collected using a data logger.

The tests have been carried out with very low amounts of solids suspended in large flows of air/ $\mathrm{CO}_{2}$ (solid-to-gas ratios below $0.06 \mathrm{~kg} / \mathrm{kg}$ ) that circulate at velocities of up to $2.2 \mathrm{~m}$ $\mathrm{s}^{-1}$ and gas/solid contact times below $1.5 \mathrm{~s}$. This operation has allowed the determination of calcination kinetics under differential conditions with respect to the gas (i.e. with modest changes in $\mathrm{CO}_{2}$ concentration in the reaction environment along the drop tube as will be seen below). The ranges of operating conditions tested in the drop tube reactor are summarized in Table 1.

Several limestones and cement raw meals have been tested (see Table 2). Compostilla and Calcare are natural

Table 1 Operating conditions tested in the drop tube during the calcination tests

Calcination temperature $\left({ }^{\circ} \mathrm{C}\right)$

790-1000

Gas velocity $\left(\mathrm{m} \mathrm{s}^{-1}\right)$

$1.1-2.2$

Inlet gas flow $\left(\mathrm{Nm}^{3} \mathrm{~h}^{-1}\right)$

Inlet $\mathrm{CO}_{2}$ volume fraction

Solids flow rate $\left(\mathrm{kg} \mathrm{h}^{-1}\right)$

$4.7-9.3$

$0-0.85$

Average particle size $(\mu \mathrm{m})$
$0.2-1.0$

7-51 
Table 2 Chemical composition and surface area of the raw meals obtained by X-ray fluorescence and $\mathrm{N}_{2}$ adsorption, respectively

\begin{tabular}{|c|c|c|c|c|c|c|c|}
\hline Oxide (wt\%) & Compostilla & Calcare & Vernasca & Marine & Geseke & Rumelange & Belitic \\
\hline $\mathrm{SiO}_{2}$ & 2.7 & 0.4 & 15.2 & 21.4 & 15.8 & 14.3 & 16.1 \\
\hline $\mathrm{P}_{2} \mathrm{O}_{5}$ & - & - & 0.1 & 0.1 & 0.1 & - & - \\
\hline $\mathrm{K}_{2} \mathrm{O}$ & 0.2 & - & 0.6 & 0.1 & 0.3 & 0.2 & 0.5 \\
\hline $\mathrm{Na}_{2} \mathrm{O}$ & - & - & - & 0.2 & 0.1 & - & - \\
\hline $\mathrm{SO}_{3}$ & 0.2 & 0.1 & 0.1 & 0.2 & 0.4 & 0.4 & 3.8 \\
\hline $\mathrm{MnO}$ & - & - & 0.1 & 0.1 & 0.1 & 0.2 & 0.1 \\
\hline $\mathrm{SrO}$ & - & - & 0.1 & 0.1 & 0.1 & 0.1 & 0.1 \\
\hline $\mathrm{ZrO}_{2}$ & - & - & - & - & 0.1 & - & - \\
\hline $\mathrm{LOI}^{a}$ & 42.6 & 44.0 & 35.3 & 32.3 & 35.4 & 34.5 & 33.2 \\
\hline BET area, $\mathrm{m}^{2} \mathrm{~g}^{-1}$ & $3.1^{1} / 4.0^{2} / 4.0^{3}$ & 1.4 & 13.5 & 13.7 & 4.3 & 6.1 & 10.8 \\
\hline
\end{tabular}

${ }^{a}$ Loss on ignition, ${ }^{1} \mathrm{CP} 1,{ }^{2} \mathrm{CP} 2,{ }^{3} \mathrm{CP} 3$.

limestones, Marine and Geseke are natural marls, and Vernasca, Belitic and Rumelange are mixtures of different limestones and natural marls. Three different fractions of Compostilla (i.e. CP1, CP2 and CP3) with different particle size distributions were obtained after milling and sieving operations in order to study the effect of the particle size and surface area on the calcination kinetics. The chemical compositions of these materials have been determined by X-ray fluorescence with a Bruker spectrometer SRS 3000. As can be seen in Table 2, both Compostilla and Calcare are limestones of high purity with very similar $\mathrm{CaO}$ content (around $52 \mathrm{wt} \%$ ). The main impurities of Compostilla and
Calcare are $\mathrm{SiO}_{2}(<3 \mathrm{wt} \%)$ and $\mathrm{MgO}(<2 \mathrm{wt} \%)$. The rest of the materials tested in this work are basically composed of $\mathrm{CaO}$ (between 37 and $42 \mathrm{wt} \%$ ), $\mathrm{SiO}_{2}$ (14 and $21 \mathrm{wt} \%$ ) and $\mathrm{Al}_{2} \mathrm{O}_{3}$ (between 3 and 5 wt\%), whose composition corresponds to typical raw meals used for clinker manufacture. ${ }^{60}$

BET surface areas were determined from nitrogen adsorption tests at $-195{ }^{\circ} \mathrm{C}$ using a Micromeritics ASAP 2460 instrument. The limestones present similar low values of BET areas in the range from 1.4 to $4 \mathrm{~m}^{2} \mathrm{~g}^{-1}$. Geseke and Rumelange also show BET areas of 4.3 and $6.1 \mathrm{~m}^{2} \mathrm{~g}^{-1}$, respectively, whereas Vernasca, Marine and Belitic exhibit
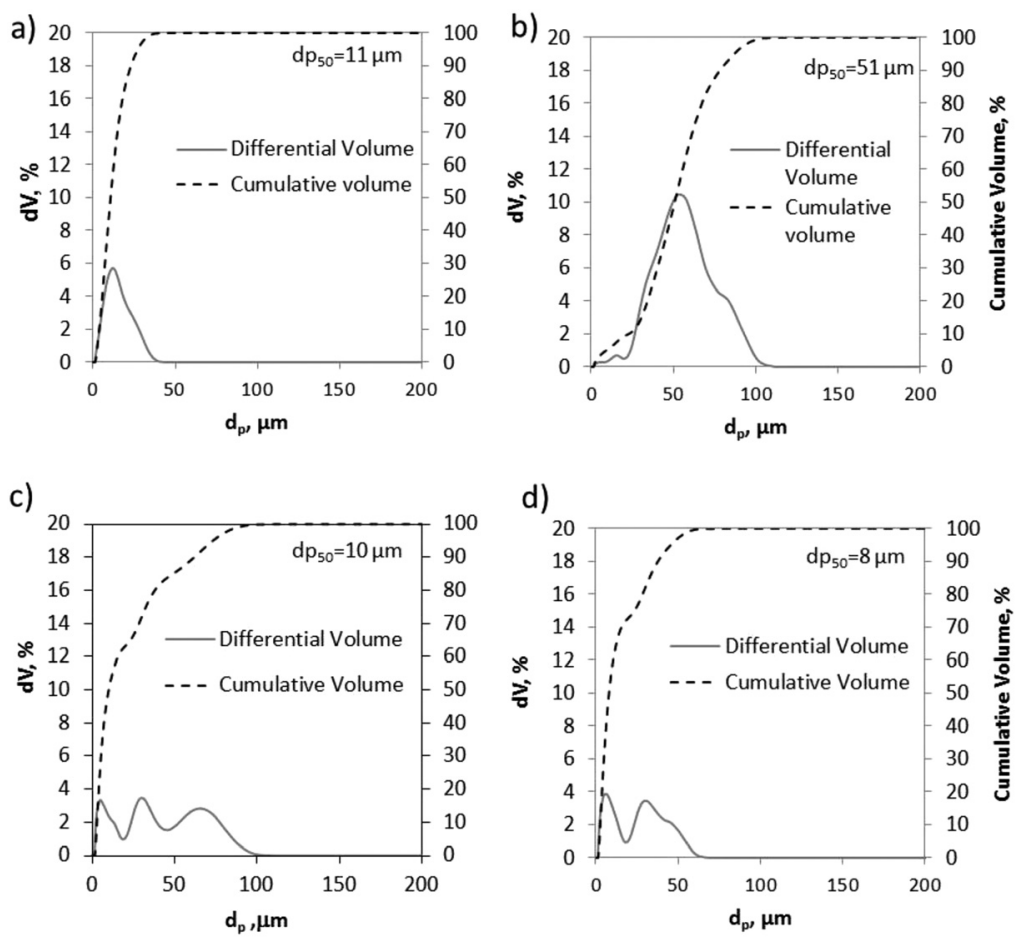

Fig. 3 Particle size distribution of different $\mathrm{CaCO}_{3}$ materials: a) $\mathrm{CP} 3$, b) $\mathrm{CP} 1$, c) Vernasca, and d) Calcare. 
noticeable higher BET areas (11-13.7 $\left.\mathrm{m}^{2} \quad \mathrm{~g}^{-1}\right)$, which correspond to typical values reported in the literature for these types of materials. ${ }^{38}$ The particle size distributions of the fresh materials were obtained by laser diffraction using an LS13320 Beckman Coulter apparatus. Fig. 3 shows the particle size distribution (PSD) and the median diameter $\left(\mathrm{dp}_{50}\right)$ of four of the $\mathrm{CaCO}_{3}$ materials tested in this work.

As can be seen, both samples of CP3 and CP1 (Fig. 3a and b, respectively) exhibit narrow PSDs with predominant volume percentages at particle diameters of about 11 and $51 \mu \mathrm{m}$. In contrast, the samples of Vernasca and Calcare (tested as they were supplied from the cement plants) show more homogeneous PSDs. The median diameters $\left(\mathrm{dp}_{50}\right)$ are 10 and $8 \mu \mathrm{m}$, with $85 \%$ and $95 \%$ volume of the particles lower than $50 \mu \mathrm{m}$, respectively. Finally, values between 7 and $11 \mu \mathrm{m}\left(\mathrm{dp}_{50}\right)$ are measured for the rest of the materials listed in Table 1.

The PSD curves of these solids are similar to those obtained for Vernasca and Calcare and they are not shown for the sake of simplicity.

The main crystalline phases present in the fresh and calcined samples of the $\mathrm{CaCO}_{3}$ materials were identified by X-ray diffraction (XRD) using a Siemens D500 powder diffractometer equipped with a copper $\mathrm{K} \alpha$ monochromatic detector. Each analysis was carried out in the $2 \theta$ range of up to $90^{\circ}$ with a step size of $0.02^{\circ}$ and a scan time per step of 1 s. Fig. 4 shows an example of X-ray spectra of fresh and calcined samples of Vernasca raw meal (at 840 and $950{ }^{\circ} \mathrm{C}$ in air). As expected in the sample of fresh raw meal, the principal peak intensities correspond to calcium carbonate and silica. In the calcined samples, apart from the peaks of $\mathrm{CaO}$, less $\mathrm{SiO}_{2}$ is measured and small amounts of calcium

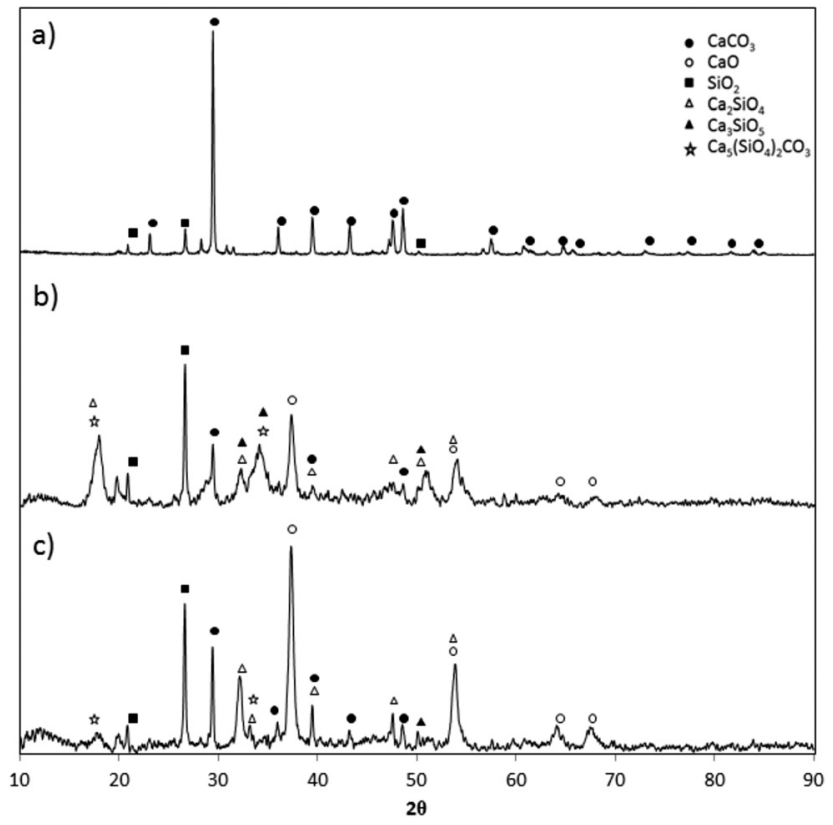

Fig. 4 X-Ray diffractograms of fresh and calcined Vernasca raw meal: a) fresh sample, b) calcined sample (at $840^{\circ} \mathrm{C}$ in air for $0.5 \mathrm{~s}$ ), and c) calcined sample (at $950{ }^{\circ} \mathrm{C}$ in air for $0.3 \mathrm{~s}$ ). silicates, mainly belite $\left(\mathrm{Ca}_{2} \mathrm{SiO}_{4}\right)$, are detected. These results confirm that the calcination of cement raw meals at temperatures above $840{ }^{\circ} \mathrm{C}$ allows appreciable amounts of calcium silicates to be irreversibly formed even for very short calcination times, which partially undermines the $\mathrm{CO}_{2}$ capture capacity of these materials. ${ }^{61}$

\section{Results and discussion}

In order to extract kinetic information from the solid conversion measurements in the drop tube apparatus, it is important to determine first the solid residence times under calcination conditions. The fine particles used in all experiments, the good level of dispersion in the carrier gas of the feeding system and the fast extraction and cooling of the solids in the isokinetic probes support the assumption that the solid residence time is the same as the gas residence time between two sections of the drop tube. To estimate possible deviations from the plug flow pattern of the gas, preliminary tests were performed to determine the residence time distribution (RTD) inside the drop tube. Abrupt variations between 12 and 0 vol\% $\mathrm{CO}_{2}$ in the inlet gas were used as tracers to obtain the experimental RTD. The degree of axial dispersion was estimated by following the methodology explained in detail in a previous study. ${ }^{39}$ Fig. 5a shows the experimental and theoretical $F(t)$ lines resulting from the step tests.

It has been calculated the dispersion of the complete system (represented in Fig. 5 as system I), which includes the drop tube, analyzer and the connecting line in between, and also the dispersion only caused by caused the analyzer and the pipeline that connects the reactor and the analyzer (represented in Fig. 5 as system I). A dispersion number $(D / \mu \mathrm{L})$ of 0.017 has been obtained for the reactor, which indicates a modest dispersion, and a dispersion coefficient $(D)$ value of $0.05 \mathrm{~m}^{2} \mathrm{~s}^{-1}$ has been calculated. Very similar values of 0.012 and $0.04 \mathrm{~m}^{2}$ $\mathrm{s}^{-1}$ can be obtained for $D / \mu \mathrm{L}$ and $D$, respectively, using a wellknown correlation reported by Levenspiel ${ }^{62}$ for the estimation of axial dispersion in pipelines. Fig. $5 \mathrm{~b}$ shows a representative $E(t)$ curve $(\mathrm{d} F / \mathrm{d} t)$ versus the normalized residence time $(\theta)$ for a dispersion number of 0.017 . As can be seen, the moderate dispersion existing in the drop tube for the conditions of this work makes the real residence time of the gas inside the reactor slightly lower than the theoretical one calculated assuming an ideal plug flow pattern (i.e. $t_{\mathrm{r}, \text { real }} / t_{\mathrm{r}, \text { theor }}=0.95$ ). This minor deviation has been considered in the calculation of the kinetic parameters explained below.

For the actual calcination experiments, different reactor lengths between 0.5 and $2.5 \mathrm{~m}$ were considered depending on the feeding and gas/solid extraction points in the test to ensure controlled and stable temperatures in the reaction zones and to facilitate the access to intermediate conversion information. The extent of the calcination conversion was obtained from measuring the variation of both the $\mathrm{CO}_{2}$ concentration in the gas phase and the carbon content of the solid samples along the reaction zone. 
a)

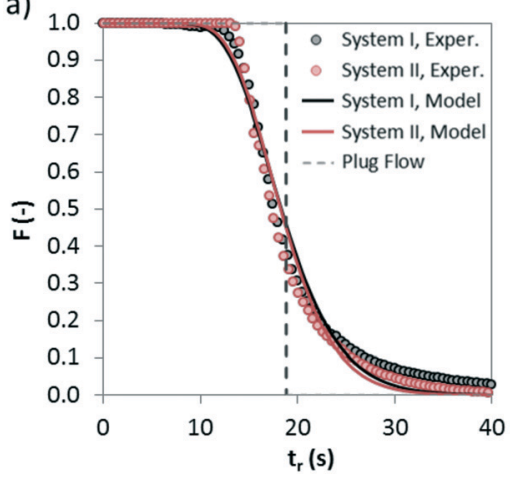

b)

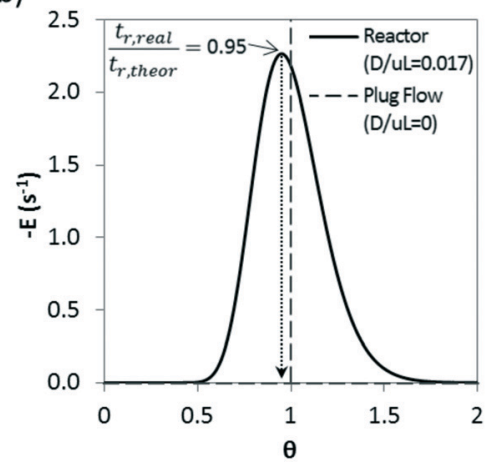

Fig. 5 a) Example of an RTD curve during step tracer experiments to estimate gas dispersion in the drop tube apparatus $\left(T=750{ }^{\circ} \mathrm{C}\right.$, inlet gas flow of $2.7 \mathrm{Nm}^{3} \mathrm{~h}^{-1}$ ). System I includes the drop tube, analyzer and connecting line and system II refers to the pipeline downstream of the reactor and the analyzer; b) deviation from ideal plug flow for a pulse input.

In a typical experiment, as shown in Fig. 6, the evolution with time of the concentration of $\mathrm{CO}_{2}$ at the inlet and outlet of the drop tube is recorded. There is a starting period, 1 , in which only the preheated mixture of air and $\mathrm{CO}_{2}$ is fed into the reactor. The inlet mass flow rates of air and $\mathrm{CO}_{2}$ are then verified by measuring the gas composition $\left(\% \mathrm{CO}_{2, \text { in }}\right)$ in the absence of a chemical reaction. In a subsequent stage, 2 , the flow of air that acts as a solids carrier is injected into the drop tube, giving as a result a dilution of the $\mathrm{CO}_{2}$ content measured in the analyzers (from 16 vol\% to about 15.5 vol\% $\mathrm{CO}_{2}$ for the particular experiment presented in Fig. 6). Once the temperature and $\mathrm{CO}_{2}$ concentration remain stable, the solids are injected to initiate the calcination period, 3. In this particular test, the variation of $\mathrm{CO}_{2}$ concentration in the gas phase has been measured at lengths of 1 and $2.5 \mathrm{~m}$ from the solids injection point $\left(\% \mathrm{CO}_{2 \text { out }}\right)$. As can be seen, the $\mathrm{CO}_{2}$ content rapidly increases due to the decomposition of $\mathrm{CaCO}_{3}$ present in the inlet solids, and after a short period of time, reasonably steady values are measured at $L=1 \mathrm{~m}(\approx 15.8$ vol\% $\left.\mathrm{CO}_{2}\right)$ and $L=2.5 \mathrm{~m}\left(\approx 16.1\right.$ vol\% $\left.\mathrm{CO}_{2}\right)$, according to the extent of the calcination conversion. After several minutes of operation under stable conditions, the addition of solids is shut off and as a consequence, the concentration of $\mathrm{CO}_{2}$

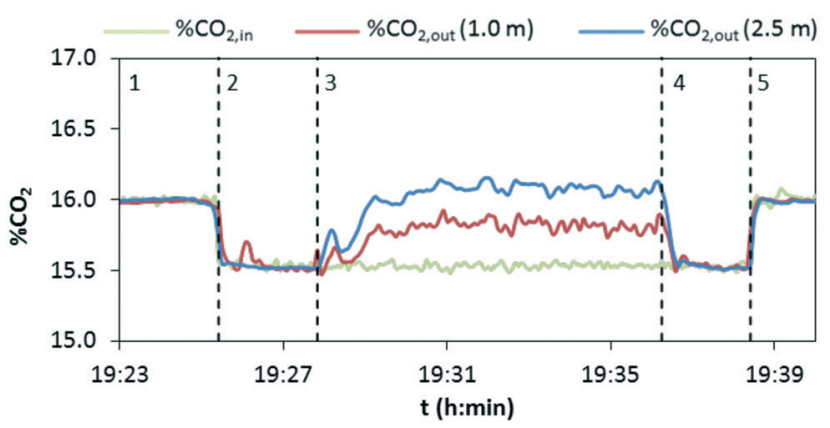

Fig. 6 Evolution of the $\mathrm{CO}_{2}$ content in the gas flowing through the drop tube in three locations during a calcination test (material: Compostilla CP1, calcination temperature $860^{\circ} \mathrm{C}$, gas velocity $=2 \mathrm{~m}$ $\mathrm{s}^{-1}$, solids flow rate $=0.65 \mathrm{~kg} \mathrm{~h}^{-1}$ ). decreases until the initial value (15.5 vol\% $\mathrm{CO}_{2}$ ) is achieved (period 4). Finally, the flow of carrier air is stopped (period 5) and the $\mathrm{CO}_{2}$ measured in the gas returns to the initial value (i.e. 16 vol\% $\mathrm{CO}_{2}$ in this case), which confirms that any alteration of the flows or possible infiltration of air in the lines has been avoided.

From the experimental information obtained in each calcination test, the following $\mathrm{CO}_{2}$ mass balance based on the gas phase has been solved to calculate the conversion of $\mathrm{CaCO}_{3}$ to $\mathrm{CaO}\left(X_{\text {calc }}\right)$ :

$$
\left(F_{\mathrm{CO}_{2} \text { out }}-F_{\mathrm{CO}_{2} \text { in }}\right)=F_{\mathrm{CaCO}_{3} \text { in }} X_{\text {calc }}
$$

where the molar flow rates of $\mathrm{CO}_{2}$ at the inlet and outlet of the drop tube, $F_{\mathrm{CO}_{2} \text { in }}$ and $F_{\mathrm{CO}_{2} \text { out }}$ respectively, can be determined from the air and $\mathrm{CO}_{2}$ flows fed into the reactor and from the measurement of the composition of the gas phase at the reactor exit. $F_{\mathrm{CaCO}_{3} \text { in }}$ refers to the amount of $\mathrm{CaCO}_{3}$ injected into the reactor during the calcination test.

It is also possible to calculate the extent of the calcination conversion by means of eqn (2) from the solids samples taken during each test, which are subjected to offline chemical analyses (explained above) to measure the variations in the carbon content along the reactor:

$$
X_{\text {calc }}=\frac{F_{\mathrm{CaCO}_{3} \text { in }}-F_{\mathrm{CaCO}_{3} \text { out }}}{F_{\mathrm{CaCO}_{3} \text { in }}}
$$

Thus, $F_{\mathrm{CaCO}_{3} \text { out }}$ is the molar flow at the exit determined from the chemical analysis of the solid particles collected. This methodology allows the internal reliability of the experimental results to be validated since the increase in the $\mathrm{CO}_{2}$ measured in the gas phase must correspond to the reduction of the carbon content measured using LECO on the solid samples.

As explained in the Introduction section, the model proposed by Borgwardt ${ }^{1}$ has been used by several authors to describe the calcination of fine particles $(<90 \mu \mathrm{m})$ of $\mathrm{CaCO}_{3}$ in air at temperatures between 700 and $1000{ }^{\circ} \mathrm{C}$, in 
which the chemical reaction is the controlling step (eqn (3)).

$$
\frac{\mathrm{d}\left(1-X_{\text {calc }}\right)}{\mathrm{d} t}=-S_{\mathrm{g}}\left(1-X_{\text {calc }}\right) k_{1}
$$

According to eqn (3), the calcination rate depends directly on the specific BET surface area $\left(S_{\mathrm{g}}\right)$ of the material. The calcination conversion $\left(X_{\text {calc }}\right)$ can then be calculated from the integrated equation (eqn (4)), in which $k_{1}$ is the reaction rate constant that follows an Arrhenius dependence on temperature.

$$
X_{\text {calc }}=1-\mathrm{e}^{-k_{1} S_{\mathrm{g}} t_{\mathrm{r}}}
$$

Fig. 7 presents the evolution of the calcination conversion of four materials taken as examples (i.e. CP1, CP2, CP3 and Calcare), obtained at temperatures between 790 and $950{ }^{\circ} \mathrm{C}$ in air atmosphere. As expected, higher temperatures and higher surface areas promote the decomposition of $\mathrm{CaCO}_{3}$. For CP2 (Fig. 7b), which exhibits a BET area of $4 \mathrm{~m}^{2} \mathrm{~g}^{-1}$ (see Table 1), almost total calcination is achieved after $1 \mathrm{~s}$ of operation at $840{ }^{\circ} \mathrm{C}$. However, less than $80 \%$ of the $\mathrm{CaCO}_{3}$ in this material is converted at $790{ }^{\circ} \mathrm{C}$ after $1.3 \mathrm{~s}$. In the case of Calcare (Fig. 7d), with a significantly lower BET area (1.4 $\mathrm{m}^{2} \mathrm{~g}^{-1}$ ), only 0.70 calcination conversion is achieved after $1 \mathrm{~s}$ at $840^{\circ} \mathrm{C}$. As can be seen, the model developed by Borgwardt
Table 3 Kinetic parameters of the calcium-based materials tested during the calcination tests $\left(E_{1}=195 \mathrm{~kJ} \mathrm{~mol}^{-1}, \Delta_{1} \mathrm{H}^{\circ}=150 \mathrm{~kJ} \mathrm{~mol}^{-1}\right)$

\begin{tabular}{lcr}
\hline Material & $a_{1}\left(\mathrm{~mol} \mathrm{~m}^{-2} \mathrm{~s}^{-1}\right)$ & \multicolumn{1}{c}{$A_{1}(-)$} \\
\hline Compostilla & $11.7 \times 10^{6}$ & $153 \times 10^{6}$ \\
Calcare & $11.9 \times 10^{6}$ & $219 \times 10^{6}$ \\
Vernasca & $2.9 \times 10^{6}$ & $137 \times 10^{6}$ \\
Marine & $3.0 \times 10^{6}$ & $43 \times 10^{6}$ \\
Geseke & $5.8 \times 10^{6}$ & $66 \times 10^{6}$ \\
Rumelange & $4.9 \times 10^{6}$ & $239 \times 10^{6}$ \\
Belitic & $1.6 \times 10^{6}$ & $28 \times 10^{6}$
\end{tabular}

predicts reasonably well the extent of the calcination conversion for the materials shown in Fig. 7 when using the activation energy reported by Borgwardt (i.e. $195 \mathrm{~kJ} \mathrm{~mol}^{-1}$ ) and when adjusting the pre-exponential factors for each material (represented as $a_{1}$ in Table 2).

However, the model proposed by Borgwardt does not take into account the effect of the $\mathrm{CO}_{2}$ content in the gas phase on the calcination rate. For this reason, a modification has been implemented in this model to solve this limitation. The kinetic rate constant has been redefined according to eqn (5).

$$
X_{\text {calc }}=1-\mathrm{e}^{-\beta\left(T, P_{\mathrm{CO}_{2}}\right) S_{\mathrm{g}} t_{\mathrm{r}}}
$$

where $\beta\left(T, P_{\mathrm{CO}_{2}}\right)$ is a function to describe the influence of the temperature and the $\mathrm{CO}_{2}$ partial pressure in the calcination a)

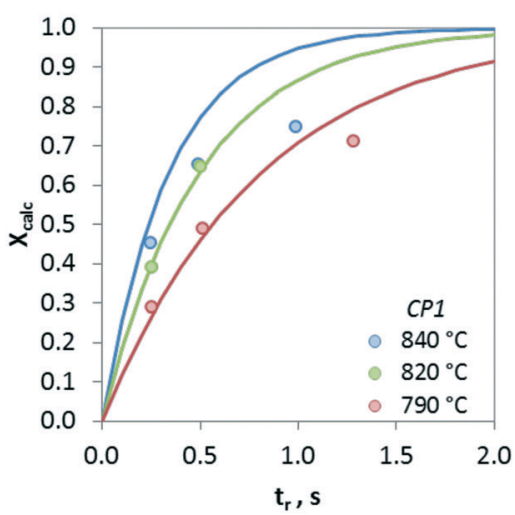

c)

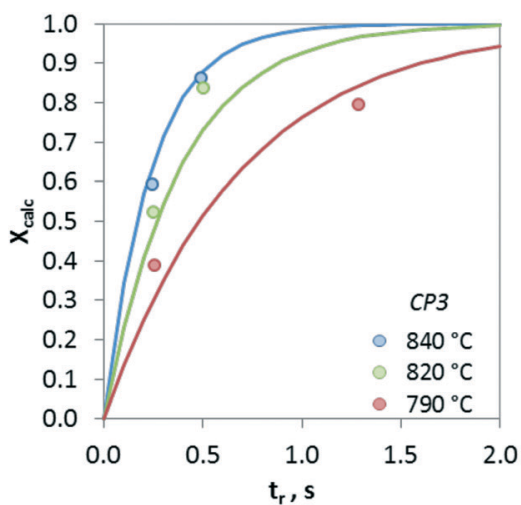

b)

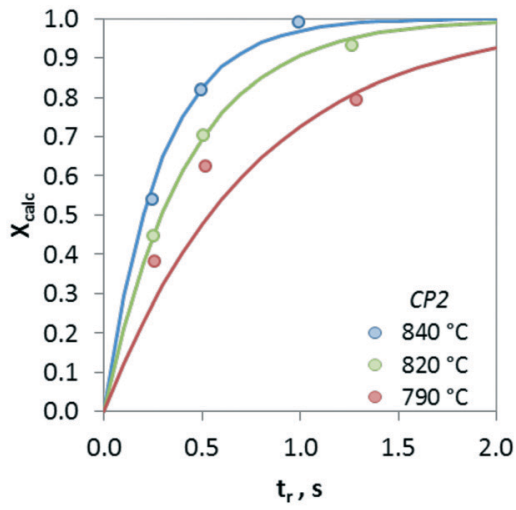

d)

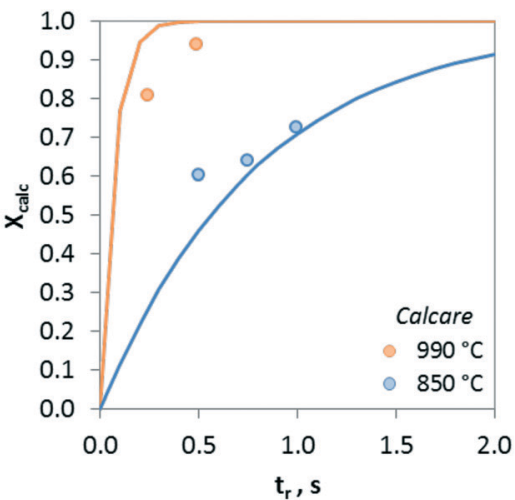

Fig. 7 Evolution of calcination conversion obtained in the drop tube under air atmosphere. a) CP1, b) CP2, c) CP3, and d) Calcare. Solid lines correspond to predictions given by Borgwardt's model with the parameters listed in Table 2. 
a)

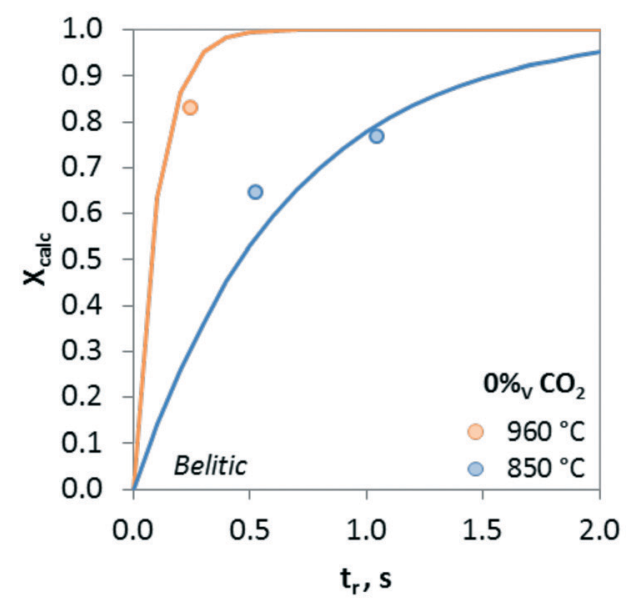

c)

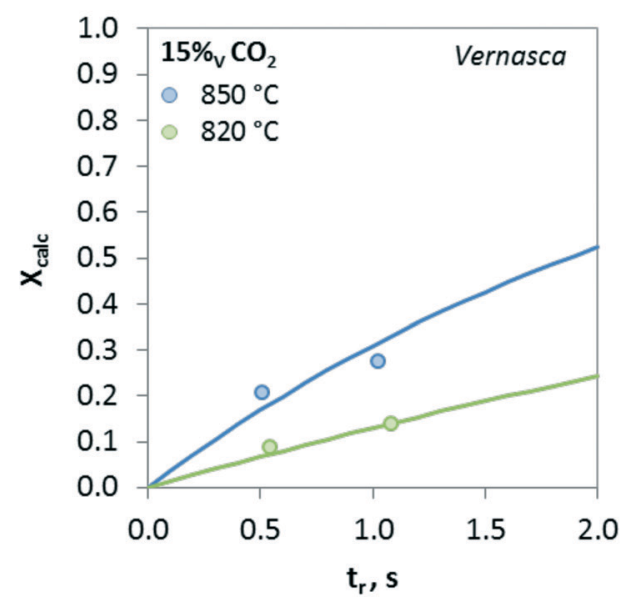

b)

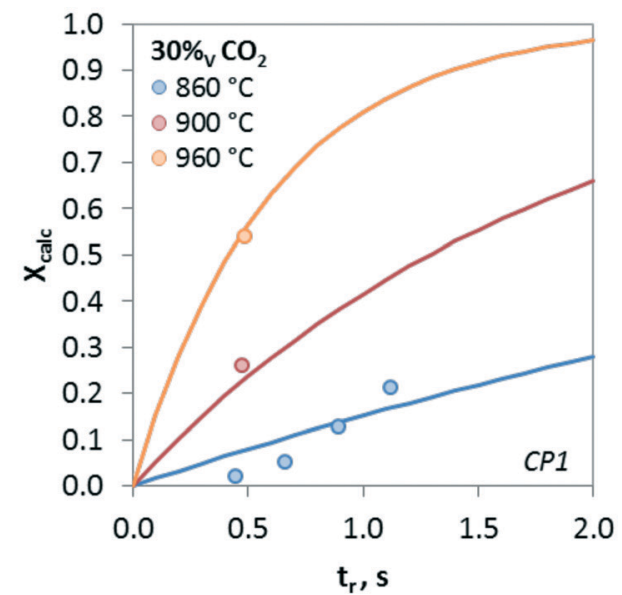

d)

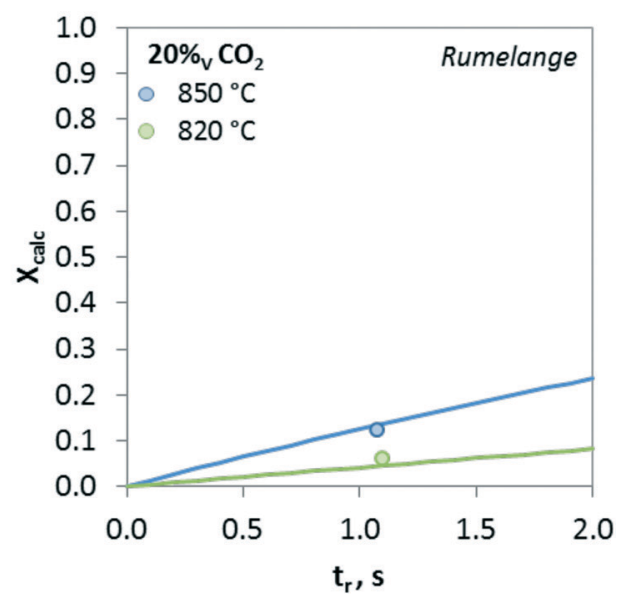

Fig. 8 Effect of temperature on the calcination conversion for $\mathrm{CaCO}_{3}$ materials of different origins and compositions. a) Belitic (mixture of limestone and marl), b) CP1 (limestone), c) Vernasca (mixture of limestone and marl), and d) Rumelange (mixture of limestone and marl). Solid lines correspond to model predictions.

kinetics. Valverde et $a l^{2}{ }^{2}$ recently formulated a theoretical model for the calcination of $\mathrm{CaCO}_{3}$ in the presence of $\mathrm{CO}_{2}$ based on a two-stage reaction mechanism. In the first stage (chemical reaction), $\mathrm{CaCO}_{3}$ decomposes to $\mathrm{CaO}$ (eqn (6)) and the resulting $\mathrm{CO}_{2}$ is adsorbed in the active sites of the solid. The chemical decomposition rate is represented by eqn (7). In the second stage, $\mathrm{CO}_{2}$ is desorbed and emitted to the gas phase (eqn (8)). The desorption rate is represented by eqn (9).

$$
\begin{gathered}
\mathrm{CaCO}_{3}+L \underset{k_{2}}{\stackrel{k_{1}}{\rightleftarrows}} \mathrm{CaO}+L\left(\mathrm{CO}_{2}\right) \\
r_{1}=k_{1}(1-\phi)-k_{2} \phi \\
L\left(\mathrm{CO}_{2}\right) \underset{k_{\mathrm{a}}}{\stackrel{k_{\mathrm{d}}}{\rightleftarrows}} L+\mathrm{CO}_{2}(\mathrm{~g}) \\
r_{2}=k_{\mathrm{d}} \phi-k_{\mathrm{a}}(1-\phi) P_{\mathrm{CO}_{2}}
\end{gathered}
$$

where $L$ denotes an active site, $L\left(\mathrm{CO}_{2}\right)$ refers to an active site with adsorbed $\mathrm{CO}_{2}, \phi$ is the fraction of active sites filled with
$\mathrm{CO}_{2}$ and $(1-\phi)$ is the fraction of empty active sites. Due to the small particle size of the solids tested in this work, the calcination process is not diffusion-limited, and consequently, the desorption of $\mathrm{CO}_{2}$ should be the fastest step and the chemical decomposition is the limiting stage. Thus, the function $\beta\left(T, P_{\mathrm{CO}_{2}}\right)$ can be represented as follows: ${ }^{2}$

$$
\beta\left(T, P_{\mathrm{CO}_{2}}\right)=k_{1}\left(1-\frac{v_{\mathrm{CO}_{2}}}{v_{\mathrm{CO}_{2}, \mathrm{eq}}}\right) \frac{1}{1+K_{1} \frac{v_{\mathrm{CO}_{2}}}{v_{\mathrm{CO}_{2}, \mathrm{eq}}}}
$$

where $k_{1}$ and $K_{1}$ are temperature-dependent constants and $v_{\mathrm{CO}_{2}}$ and $v_{\mathrm{CO}_{2}}$,eq are the $\mathrm{CO}_{2}$ volume fractions present in the reaction atmosphere and at the equilibrium, respectively. The kinetic constant $k_{1}$ has an Arrhenius dependence on temperature and the decomposition thermodynamic equilibrium constant $K_{1}$ varies with temperature following the van't Hoff equation (eqn (11)).

$$
K_{1}=\frac{k_{1}}{k_{2}}=A_{1} \mathrm{e}^{\left(-\Delta_{1} H^{\circ} / R T\right)}
$$



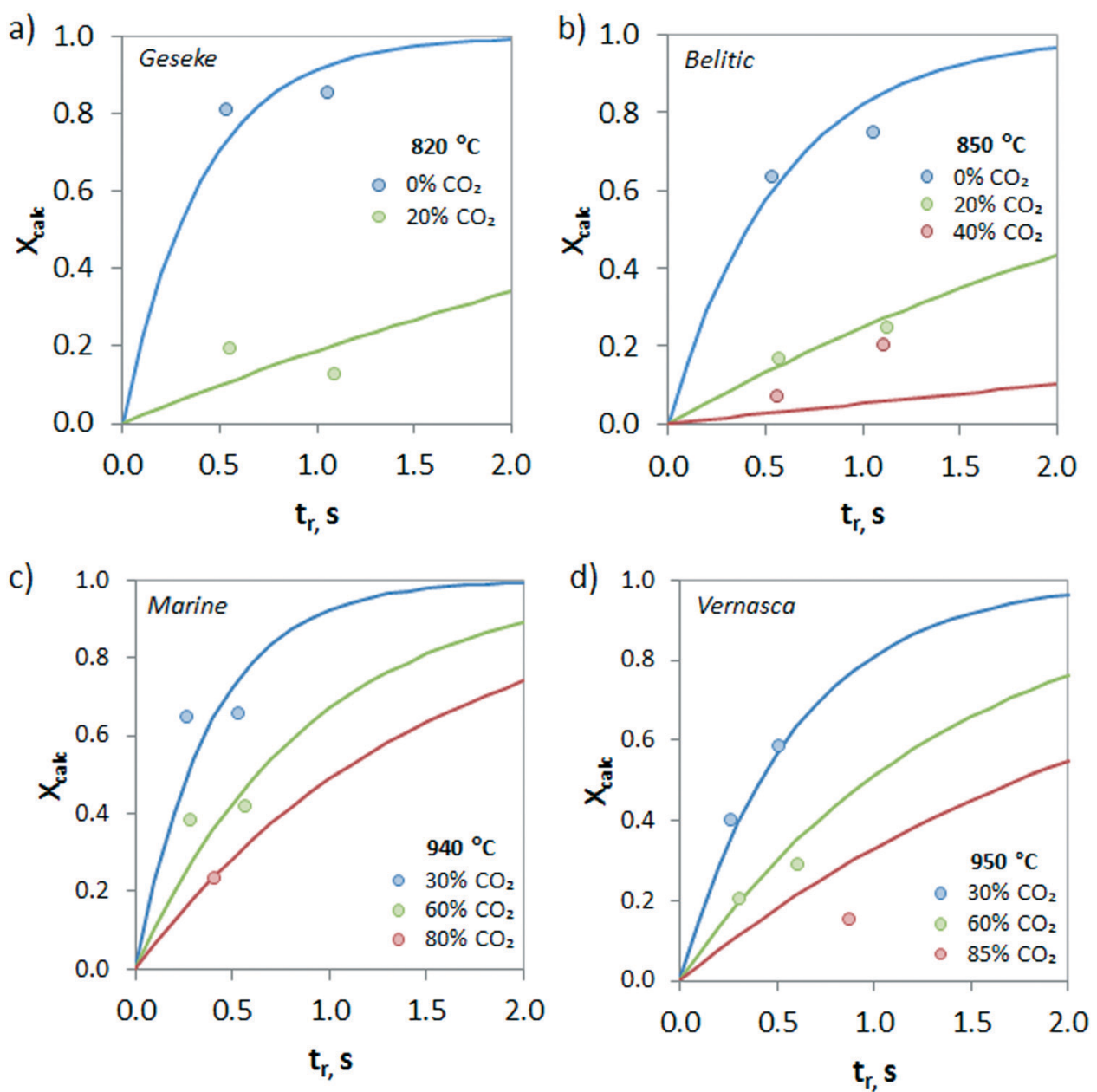

Fig. 9 Effect of the concentration of $\mathrm{CO}_{2}$ in the gas phase on the calcination conversion for $\mathrm{CaCO}_{3}$ materials of different origins and compositions. a) Geseke (marl), b) Belitic (mixture of limestone and marl), c) Marine (marl), and d) Vernasca (mixture of limestone and marl). Solid lines correspond to model predictions.

a)

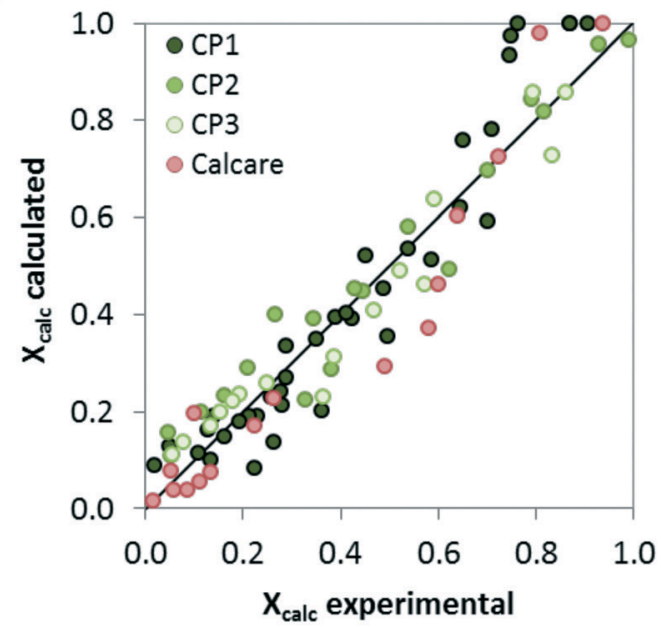

b)

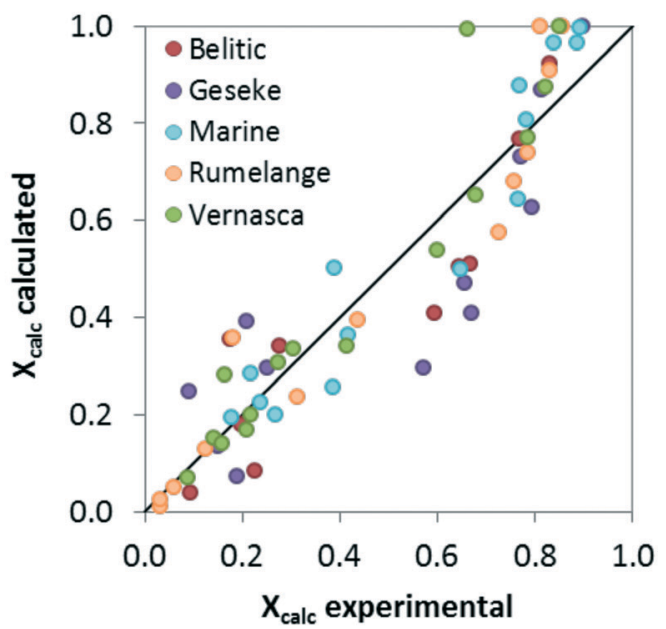

Fig. 10 Comparison between the calcination conversions obtained in the drop tube and the values given by the proposed model assuming the kinetic parameters listed in Table 3. a) Limestones, b) marls and mixed Ca-Si materials. 
where $A_{1}$ and $\Delta_{1} H^{\circ}$ refer to the standard entropy and enthalpy changes of the $\mathrm{CaCO}_{3}$ decomposition reaction, respectively. $^{2}$ The combination of the previous equations gives as a result the final equation (eqn (12)) for the calculation of the calcination conversion, which corresponds to eqn (4) (ref. 1) when $\mathrm{CO}_{2}$ is absent in the reaction atmosphere (i.e. $v_{\mathrm{CO}_{2}}=0$ ).

$$
X_{\text {calc }}=1-\mathrm{e}^{-a_{1} \mathrm{e}^{\left(-E_{1} / R T\right)}\left(1-\frac{v_{\mathrm{CO}_{2}}}{v_{\mathrm{CO}_{2}, \mathrm{eq}}}\right) \frac{1}{1+A_{1} \mathrm{e}^{\left(-\Delta_{1} H^{\circ} / R T\right)} \frac{{ }^{{ }_{\mathrm{CO}}} \mathrm{CO}_{2}}{{ }^{\mathrm{CO}_{2}, \mathrm{eq}}}} S_{\mathrm{g}} t_{\mathrm{r}}}
$$

The same values reported by Borgwardt ${ }^{1}$ for the activation energy (i.e. $195 \mathrm{~kJ} \mathrm{~mol}^{-1}$ ) and by Valverde et al. ${ }^{2}$ for $\Delta_{1} H^{\circ}$ (i.e. $150 \mathrm{~kJ} \mathrm{~mol}^{-1}$ ) have been assumed in this work. The kinetic parameters $a_{1}$ and $A_{1}$ have been calculated for each $\mathrm{CaCO}_{3}$ based material by fitting the experimental data (see Table 3 ).

Fig. 8 shows the effect of the temperature on the calcination conversion of $\mathrm{CaCO}_{3}$ materials of different origins and compositions. As expected, the calcination temperature has a strong effect on $X_{\text {calc }}$. Thus, temperatures above $900{ }^{\circ} \mathrm{C}$ promote the calcination reaction and $X_{\text {calc }}$ values higher than 0.5 are achieved for residence times below $0.5 \mathrm{~s}$ in the drop tube, regardless of whether the solid is a limestone or a mixture of $\mathrm{CaCO}_{3}$ and $\mathrm{SiO}_{2}$. However, the calcination conversions at $820{ }^{\circ} \mathrm{C}$ for longer reaction times $\left(t_{\mathrm{r}}>1 \mathrm{~s}\right)$ are lower than 0.15 .

The evolution of the calcination conversion under different $\mathrm{CO}_{2}$ concentrations (from 0 to $85 \mathrm{vol} \%$ ) is presented in Fig. 9. As can be seen, increasing contents of $\mathrm{CO}_{2}$ in the atmosphere hinder the calcination of $\mathrm{CaCO}_{3}$ due to equilibrium restrictions, and consequently, lower $X_{\text {calc }}$ values are obtained for the same operating temperature. However, it must be highlighted that relevant calcination conversions can be achieved under high $\mathrm{CO}_{2}$ concentrations even at very short reaction times. As an example, samples of Belitic (mixture of limestone and marl) achieved a solid conversion of 0.2 in approximately $1 \mathrm{~s}$ in the drop tube when the calcination was carried out at $850{ }^{\circ} \mathrm{C}$ under 40 vol\% $\mathrm{CO}_{2}$ (Fig. 9b). In the case of Marine (marl), an $X_{\text {calc }}$ of 0.2 was achieved in less than $0.5 \mathrm{~s}$ under $80 \mathrm{vol} \% \mathrm{CO}_{2}$ at $940{ }^{\circ} \mathrm{C}$ (Fig. 9c).

Finally, the comparison between the calcination conversions obtained experimentally in the drop tube and the calculated values using the proposed model with the kinetic parameters listed in Table 3 is presented in Fig. 10. As can be seen, despite the modest regression coefficients $\left(R^{2}\right.$ values of 0.91 and 0.86 have been obtained for limestone and $\mathrm{CaCO}_{3}-\mathrm{SiO}_{2}$ materials, respectively) the model predicts reasonably well the extent of the solids conversion for each material, in particular when considering the inherent limitations of the experimental set up and the short gas-solid contact times used in this study.

These results confirm that high solid conversions can be obtained with $\mathrm{CaCO}_{3}$ materials of different characteristics when the calcination is carried out under typical conditions of calcium looping systems highly integrated in cement plants.

\section{Conclusions}

The calcination of several high purity limestones, natural marls and combined $\mathrm{CaCO}_{3}-\mathrm{SiO}_{2}$ raw meals has been investigated in an electrically heated drop tube under relevant conditions of a calcium looping process integrated in a cement plant. The calcination tests have been carried out with fine solids with average particle sizes below $50 \mu \mathrm{m}$, at temperatures between 790 and $1000{ }^{\circ} \mathrm{C}$ and $\mathrm{CO}_{2}$ contents in the atmosphere up to 85 vol\%. As expected, higher temperatures and lower concentrations of $\mathrm{CO}_{2}$ in the gas favour the calcination of $\mathrm{CaCO}_{3}$ regardless of whether the solid is a limestone or a combined $\mathrm{Ca}-\mathrm{Si}$ material. Calcination conversions higher than 0.5 have been achieved at temperatures above $900{ }^{\circ} \mathrm{C}$ for residence times of the solids in the drop tube of about $1 \mathrm{~s}$. XRD analyses show that a certain amount of calcium silicates is also formed during the calcination at temperatures above $840{ }^{\circ} \mathrm{C}$. The calcination of all the materials tested in this work can be reasonably well described by means of a standard calcination model, in which the reaction rate depends directly on the specific BET surface area of the solid and the activation energy takes a value of $195 \mathrm{~kJ} \mathrm{~mol}^{-1}$. Both experimental and kinetic studies should provide valuable information for the progress of calcium looping integrated in cement plants.

\section{Conflicts of interest}

There are no conflicts to declare.

\section{Acknowledgements}

This investigation has been funded by the European Union's Horizon 2020 Research and Innovation Programme under the H2020 grant agreement no. 764816 (CLEANKER Project).

\section{Notes and references}

1 R. H. Borgwardt, AIChE J., 1985, 31, 103-111.

2 J. M. Valverde, P. E. Sanchez-Jimenez and L. A. PerezMaqueda, J. Phys. Chem. C, 2015, 119, 1623-1641.

3 J. C. Abanades, B. Arias, A. Lyngfelt, T. Mattisson, D. E. Wiley, H. Li, M. T. Ho, E. Mangano and S. Brandani, Int. J. Greenhouse Gas Control, 2015, 40, 126-166.

4 D. P. Hanak, E. J. Anthony and V. Manovic, Energy Environ. Sci., 2015, 8, 2199-2249.

5 I. Martínez, G. Grasa, J. Parkkinen, T. Tynjälä, T. Hyppänen, R. Murillo and M. C. Romano, Int. J. Greenhouse Gas Control, 2016, 50, 271-304.

6 M. E. Diego, B. Arias and J. C. Abanades, J. Cleaner Prod., 2016, 117, 110-121.

7 M.-H. Chang, C.-M. Huang, W.-H. Liu, W.-C. Chen, J.-Y. Cheng, W. Chen, T.-W. Wen, S. Ouyang, C.-H. Shen and H.-W. Hsu, Chem. Eng. Technol., 2013, 36, 1525-1532. 
8 J. Hilz, M. Haaf, M. Helbig, N. Lindqvist, J. Ströhle and B. Epple, Int. J. Greenhouse Gas Control, 2019, 88, 332-341.

9 G. S. Grasa and J. C. Abanades, Chem. Eng. Sci., 2007, 62, 619-626.

10 M. Reitz, M. Junk, J. Ströhle and B. Epple, Int. J. Greenhouse Gas Control, 2016, 54, 272-281.

11 D. Hoeftberger and J. Karl, J. Energy Resour. Technol., 2016, 138, 042211.

12 T. P. Hills, M. Sceats, D. Rennie and P. Fennell, Energy Procedia, 2017, 114, 6166-6170.

13 J. Wolf and J. Yan, Int. J. Eng. Res., 2005, 29, 739-753.

14 M. E. Diego, B. Arias, A. Méndez, M. Lorenzo, L. Díaz, A. Sánchez-Biezma and J. C. Abanades, Int. J. Greenhouse Gas Control, 2016, 50, 14-22.

15 J. R. Fernández and J. C. Abanades, J. Cleaner Prod., 2016, 112, 1211-1217.

16 R. V. Kumar, R. K. Lyon and J. A. Cole, in Advances in Hydrogen Energy, ed. C. E. Grégoire Padró and F. Lau, Springer, US, Boston, MA, 2002, pp. 31-45, DOI: 10.1007/0306-46922-7_3.

17 J. C. Abanades, R. Murillo, J. R. Fernandez, G. Grasa and I. Martínez, Environ. Sci. Technol., 2010, 44, 6901-6904.

18 B. Arias, M. E. Diego, A. Méndez, M. Alonso and J. C. Abanades, Fuel, 2018, 222, 711-717.

19 ECRA, CCS-Carbon Capture and Storage, Available online: https://ecra-online.org/research/ccs/.

20 S. O. Gardarsdottir, E. De Lena, M. Romano, S. Roussanaly, M. Voldsund, J.-F. Pérez-Calvo, D. Berstad, C. Fu, R. Anantharaman, D. Sutter, M. Gazzani, M. Mazzotti and G. Cinti, Energies, 2019, 12, 542.

21 N. Rodríguez, R. Murillo and J. C. Abanades, Environ. Sci. Technol., 2012, 46, 2460-2466.

22 L. M. Romeo, D. Catalina, P. Lisbona, Y. Lara and A. Martínez, Greenhouse Gases: Sci. Technol., 2011, 1, 72-82.

23 A. Telesca, D. Calabrese, M. Marroccoli, M. Tomasulo, G. L. Valenti, G. Duelli and F. Montagnaro, Fuel, 2014, 118, 202-205.

24 K. Vatopoulos and E. Tzimas, J. Cleaner Prod., 2012, 32, 251-261.

25 IEA and CSI, Technology Roadmap: Low-Carbon Transition in the Cement Industry, International Energy Agency, Cement Sustainability Initiative, 2018.

26 A. Rolfe, Y. Huang, M. Haaf, A. Pita, S. Rezvani, A. Dave and N. J. Hewitt, Int. J. Greenhouse Gas Control, 2018, 75, 85-97.

27 D. C. Ozcan, H. Ahn and S. Brandani, Int. J. Greenhouse Gas Control, 2013, 19, 530-540.

28 K. Atsonios, P. Grammelis, S. K. Antiohos, N. Nikolopoulos and E. Kakaras, Fuel, 2015, 153, 210-223.

29 M. C. Romano, M. Spinelli, S. Campanari, S. Consonni, M. Marchi, N. Pimpinelli and G. Cinti, Energy Procedia, 2014, 61, 500-503.

30 M. Spinelli, I. Martínez and M. C. Romano, Chem. Eng. Sci., 2018, 191, 100-114.

31 E. De Lena, M. Spinelli, I. Martínez, M. Gatti, R. Scaccabarozzi, G. Cinti and M. C. Romano, Int. J. Greenhouse Gas Control, 2017, 67, 71-92.
32 M. Spinelli, I. Martínez, E. De Lena, G. Cinti, M. Hornberger, R. Spörl, J. C. Abanades, S. Becker, R. Mathai, K. Fleiger, V. Hoenig, M. Gatti, R. Scaccabarozzi, S. Campanari, S. Consonni and M. C. Romano, Energy Procedia, 2017, 114, 6206-6214.

33 E. De Lena, M. Spinelli, M. Gatti, R. Scaccabarozzi, S. Campanari, S. Consonni, G. Cinti and M. C. Romano, Int. J. Greenhouse Gas Control, 2019, 82, 244-260.

34 B. Arias, M. Alonso and C. Abanades, Ind. Eng. Chem. Res., 2017, 56, 2634-2640.

35 M. Hornberger, R. Spörl and G. Scheffknecht, Energy Procedia, 2017, 114, 6171-6174.

36 S. K. Pathi, W. Lin, J. B. Illerup, K. Dam-Johansen and K. Hjuler, Energy Fuels, 2013, 27, 5397-5406.

37 M. Alonso, Y. Álvarez Criado, J. R. Fernández and C. Abanades, Energy Fuels, 2017, 31, 13955-13962.

38 J. Plou, I. Martínez, G. S. Grasa and R. Murillo, React. Chem. Eng., 2019, 4, 899-908.

39 S. Turrado, B. Arias, J. R. Fernández and J. C. Abanades, Ind. Eng. Chem. Res., 2018, 57, 13372-13380.

40 J. Khinast, G. F. Krammer, C. Brunner and G. Staudinger, Chem. Eng. Sci., 1996, 51, 623-634.

41 C. N. Satterfield and F. Feakes, AIChE J., 1959, 5, 115-122.

42 T. R. Ingraham and P. Marier, Can. J. Chem. Eng., 1963, 41, 170-173.

43 A. W. D. Hills, Chem. Eng. Sci., 1968, 23, 297-320.

44 F. R. Campbell, A. W. D. Hills and A. Paulin, Chem. Eng. Sci., 1970, 25, 929-942.

45 D. Beruto and A. W. Searcy, J. Chem. Soc., Faraday Trans. 1, 1974, 70, 2145-2153.

46 J. S. Dennis and A. N. Hayhurst, Chem. Eng. Sci., 1987, 42, 2361-2372.

47 N. Hu and A. W. Scaroni, Fuel, 1996, 75, 177-186.

48 F. García-Labiano, A. Abad, L. F. de Diego, P. Gayán and J. Adánez, Chem. Eng. Sci., 2002, 57, 2381-2393.

49 I. Martínez, G. Grasa, R. Murillo, B. Arias and J. C. Abanades, Energy Fuels, 2012, 26, 1432-1440.

50 C. R. Milne, G. D. Silcox, D. W. Pershing and D. A. Kirchgessner, Ind. Eng. Chem. Res., 1990, 29, 139-149.

51 G. D. Silcox, J. C. Kramlich and D. W. Pershing, Ind. Eng. Chem. Res., 1989, 28, 155-160.

52 J. Ylätalo, J. Parkkinen, J. Ritvanen, T. Tynjälä and T. Hyppänen, Fuel, 2013, 113, 770-779.

53 J. Szekely and J. W. Evans, Chem. Eng. Sci., 1970, 25, 1091-1107.

54 F. Fang, Z.-S. Li and N.-S. Cai, Energy Fuels, 2009, 23, 207-216.

55 M. S. Murthy, B. R. Harish, K. S. Rajanandam and K. Y. Ajoy Pavan Kumar, Chem. Eng. Sci., 1994, 49, 2198-2204.

56 T. Rajeswara Rao, D. J. Gunn and J. H. Bowen, Chem. Eng. Res. Des., 1989, 67, 38-47.

57 A. G. Okunev, S. S. Nesterenko and A. I. Lysikov, Energy Fuels, 2008, 22, 1911-1916.

58 C. Qin, D. He, Z. Zhang, L. Tan and J. Ran, Chem. Eng. J., 2018, 334, 2238-2249. 
59 D. He, Z. Ou, C. Qin, T. Deng, J. Yin and G. Pu, Chem. Eng. J., 2020, 379, 122348.

60 H. F. Taylor, Cement chemistry, Thomas Telford, 1997.
61 M. Alonso, J. R. Fernández and J. C. Abanades, Ind. Eng. Chem. Res., 2019, 58, 5445-5454.

62 O. Levenspiel, J. Ind. Eng. Chem., 1958, 50, 343-346. 